\title{
消波ブロックの比重変化が安定性に及隹す影響について \\ On an effect of Specific-gravity Change for Stability in Armor Unit
}

\author{
伊藤政博 * 岩垣雄一” \\ Masahi ro. I to, Yuichi. Iwagaki \\ 根本建治”* - 山本方人“. 半沢 稔” \\ Kenji. Nemoto, Masato. Yamamoto, Minoru. Hanzawa
}

\begin{abstract}
From Hudson's formula, armor unit weight is found to be proportional to specific gravity to the 3 rd power if wave height, slope angle, and stability coefficient are constant. Then, it is expected that the specific gravity becomes heavier, the stability for wave become very higher. To check these properties, laboratory rests on the stability were conducted with 2-layer covered breakwater by 6 types of tetrapod mocels for 5 kinds of specific gravities; $1.82,2.30$, 2. 77, 3. 40, and 4.27, under no-overtopping condition. The effect of specific gravity upon the stability of armor unit is examined by using experimental data.

Keywords; heavy armor unit, stability, surf similarity parameter, tetrapod
\end{abstract}

\section{1.はじめに}

防波堤の消波工や捨石堤の被覆工として消波ブロックを使用する場合, 設計波高に対する消波ブロックの所要 重量はHudson式”で算出している. Hudson式中の安定係数 $\mathrm{K}_{\mathrm{U}}$ は，数多くの水槽実験に基づいて，消波ブロックの 設置場所（防波堤法面, 天端）及び波の特性（碎波, 非砕波）に応じた值が定められている。この式によると， 安定係数, 法面勾配及びコンクリートの比重が一定の下では, 消波ブロックの所要重量は入射波高の 3 乗に比例 するので, 波高の増大に伴って所要重量が飛躍的に重くなる。したがって，離島など大きな施工機械が利用でき ない場所やその他の制約などから，小さい消波ブロックで，大きな波高に耐えられるようにしなければならない ことが多い。このような場合には，普通コンクートより比重を重くした高比重の消波ブロックの使用が有効であ ると考えられる。このような目的で, 高比重テトラポッドに関して, 高吉・高橋・徳川2゙ら, 高知県室津港の 防波堤前面の消波工として使用するために, 通常のコンクリート比重2.3のほか2.55のテトラポッドと2.3のドロ スについて，現地波浪を想定した模型実験を行っている，その結果，テトラポッドの比重を重くすることによっ て, 被害率が小さくなることを指摘している，また，Zwamborn ${ }^{33}$ は，ドロスの比重を2.31，2.41，2.57の 3 種類 に変えた小規模な水槽実験を行い，ブロックのロッキング及び移動に及ぼす比重の影響を調べている．この研究 方法は, ブロック形状が同じならば比重の增大に伴ってドロスの重量る大きくなるので, 真に比重の効果を調べ たことにはならいが，実験によれば比重の増大によって，ロッキングや移動がかなり減少することを示した．ま た, 最近, 大中・石崎・堺“'は比重の重いブロックの安定性を調べる研究を始めている，大中らの研究は，形状 寸法及び体積が同じで比重2.25，2.43，3.14，4.04の模型のテトラポッドに規則波及び不規則波を作用させた実 験を行い, 比重の增加に伴って，安定性が相対的に低下する傾向にあることを指摘している．ただし，この研究 方法では，波高が大きくなるにつれて消波工の法肩及び越波などが生じやすくなるので，ことに注意を要する。

このように, 最近, わが国や諸外国において，此重を重くしてブロックの耐波性能を向上させる基礎的な研究 が行われるようになった。ししかし, 従来から慣用されているHudson式による安定係数は, 普通コンクリート（比 重2.3）の模型を用いて実験的に定められたすのであって, 比重を变えた場合について, Hudson式そのものや, 慣 用されている安定係数の適用性を調べた基礎的な研究はほとんどない，このような背景から，消波ブロックとし てテトラポッドを用い，比重の変化（比重1.82．2.30．2.77３.40.4.27）による水理特性を詳しく調べる.

\section{Hudson式による比重の影響ら}

Hudson式に基づいて，比重の変化が各諸量にどのような影響を与えるかについて検討を加える，ただし，K $\mathrm{K}_{\mathrm{L}}$ 値 は比重が変化しても一定であると仮定すれば，波高H，法面角度が一定のとき，消波ブロックの比重変化が所要

* 正会員 名城大学理工学部土木工学科 (

** 正会員 日本テトラポッド株式会社応用水理研究所 
重量に及ばす影響は，テトラポッドの任意比重 $w_{r}$ / / と普通コンク リート比重 $w_{r} / w(=2.30)$ との比を $w_{r *} / w_{r}$ 。で表わすと, 任意比重と 普通コンクリートによる所要重量比 $\mathrm{W}+/ \mathrm{W}$ 。は, 次式のようになる.

$$
\frac{W_{*}}{W_{0}}=\frac{w_{r} \cdot\left\{\left(w_{r} / w\right)-1\right\}^{3}}{w_{r} \cdot\left(\left(w_{r}+/ w\right)-1\right\}^{3}}
$$

また，ブロックの代表寸法（形状高）をlとすれば，kを比例定数 として,

$$
\mathrm{W}=\mathrm{kW}_{\mathrm{r}} \mathrm{l}^{3}
$$

で表わされるから，比例定数を一定とすれば，任意比重と普通コ ンクリートによる寸法比1./1。は，次のように表される。

$$
\frac{1}{l_{0}}=\left(\frac{\mathrm{W} * \mathrm{~W}_{\mathrm{r}}}{\mathrm{W}_{0} \mathrm{~W}_{\mathrm{r}}}\right) 1 / 3
$$

いま, 式(2), (3)の関係を用いて, 比重の変化が所要重量に及ぼ す影響が，図一1に示してある。さらに，この図の横軸には，相 対比重比の関係が分かりやすいように比重W $w_{0}$ /wの值が併示してあ る.このことから, 外力としての波高が一定であっても, 比重を 重くすることによって，ブロックの所要重量と形状寸法が相対的 に小さくなっても安定となることがわかる。

\section{3. 実験装置および方法}

\section{(1) 実験装置}

a)平面水槽

長さ $18 \mathrm{~m}$, 幅 $10 \mathrm{~m}$, 深さ $1.17 \mathrm{~m}$ の平面水槽内を, コンクリート板で 仕切って, 四っの小水槽（A， B , C, D ）を造った。テトラポ ッドで被稪した防波堤消波工と造波板との間に生じる波の多重再 反射を防ぐために，消波マットからなる反射波吸収斜面(1：5) をそれぞれ $\mathrm{A} \sim \mathrm{D}$ の小水槽の間に設置した。そのために，模型に 長時間波を作用させても比較的きれいな波形の安定した実験波を 得ることができる。

\section{b)造波装置}

造波装置は，造波板（偪 $6.5 \mathrm{~m} ，$ 高さ $90 \mathrm{~cm}$ ）が吊り下げてあり， 前後に振れるピストン式である。水深は $60 \mathrm{~cm}$ とし, 特にB水槽で は, 周期 $\mathrm{T}=1.5,2.0 ， 2.5 \mathrm{sec}$, 最大波高 $32 \mathrm{~cm}$ を発生させること ができる。さらに，大きな波高が必要な消波ブロックについては 日本テトラポッド(株)の，二次元造波水槽を用いた。これらの実 験条件をまとめれば表一1のようになる。

c)测定装置

波によるテトラポッドの移動状況は, SONY CCD-V88の8mmビデオ カメラで撮影し,ナショナルAG-3530再生装置およびSONY KV14MD1テレビで再生し，ブロックの摇動・移動・脱落の状況を調べ

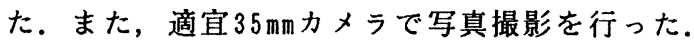

d) 模型消波工

模型の消波工は，中心部に捨石として $38 \mathrm{gf}($ 径 $47 \mathrm{~mm}$ ）の砕石を 使用した。ただし，テトラポッド模型の下層捨石は，一般にブロ ック重量の1/10〜1/20とされているので, 各種のテトラポッド模 型の大きさに合うように，A 水槽には $24 \mathrm{gf}$ (平均粒径 $41 \mathrm{~mm}$ )，水 槽 B.には，29gf（平均粒径 $43 \mathrm{~mm}$ ），水槽 Cには7. $5 \mathrm{gf}$ （平均粒径 $27 \mathrm{~mm}$ ），水槽 D には $3 \mathrm{gf}$ （平均粒径 $21 \mathrm{~mm}$ ）の砕石を使用した。

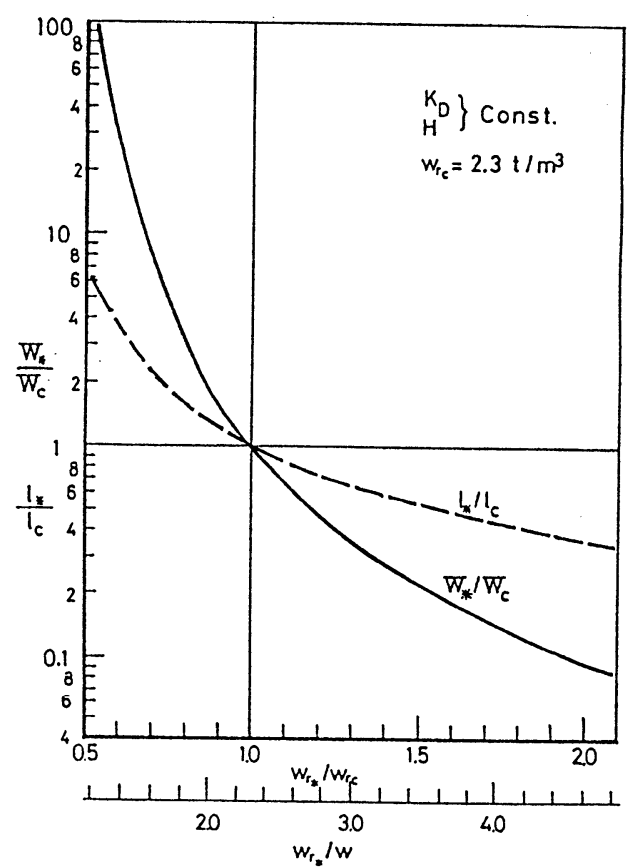

図一1比重の変化が所要重量及び形状寸法に 及ぼす影響, $\mathrm{K}_{\mathrm{V}}, \mathrm{H}$; 一定

\begin{tabular}{|c|c|c|c|c|c|c|c|}
\hline \multirow{2}{*}{ 檴 } & 蹯曽 & 5 & 4 & 3 & 2 & 1 & \multirow{2}{*}{ 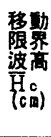 } \\
\hline & $w_{r} \cdot / w$ & 1.82 & 2.30 & 2.77 & 3. 40 & 4. 27 & \\
\hline \multirow{2}{*}{ A } & $8(\mathrm{~cm})$ & 7.16 & 4. 52 & 3.29 & & & \multirow{2}{*}{8.6} \\
\hline & $w(g f)$ & 186.4 & 58.9 & 27.7 & & & \\
\hline \multirow{2}{*}{ B } & $\ell(\mathrm{cm})$ & 9.04 & 5.68 & 4. 14 & & & \multirow{2}{*}{10.8} \\
\hline & $w(g f)$ & 372.7 & 117.8 & 55.4 & & & \\
\hline \multirow{2}{*}{ c } & $8(\mathrm{~cm})$ & 12.24 & 7.72 & 5.68 & 4.14 & 3.08 & \multirow{2}{*}{14.7} \\
\hline & $m(g f)$ & 931.8 & 294.4 & 141.8 & 68.0 & 34.2 & \\
\hline \multirow{2}{*}{$D$} & $\&(\mathrm{~cm})$ & 16.62 & 10.48 & 7.72 & 5.68 & 4. 14 & \multirow{2}{*}{19.9} \\
\hline & $w(g t)$ & 2329.6 & 736.0 & 354.6 & 174.1 & 85.4 & \\
\hline \multirow{2}{*}{$E$} & $\ell(\mathrm{cm})$ & & 14.15 & 10.48 & 1.72 & 5.68 & \multirow{2}{*}{26.9} \\
\hline & $w(8)$ & & 1811.0 & 886.4 & 435. 2 & 218.6 & \\
\hline \multirow{2}{*}{$F$} & $\ell(\mathrm{cm})$ & & 8.28 & & & & \multirow{2}{*}{15.7} \\
\hline & $w(g)$ & & 368.0 & & & & \\
\hline
\end{tabular}

表一 1 実験条件の概要

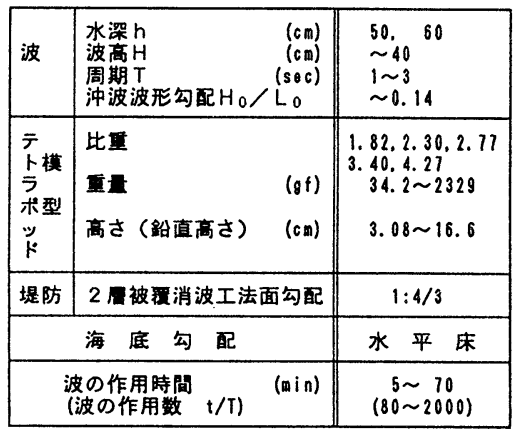


テトラポッドの被覆斜面勾配は1：4/3とし, 法面に模型のテ トラポッドを積み, 非越波とした。テトラポッドの積み方は, 2 首の整積み及び乱積みの 2 種類しした。

e)テトラポッド模型

比重の効果を詳しく調べるために，テトラポッドの模型は 普通コンクリート（比重2.30）を基準にし，比重が1.82，2. 30，2.77，3.40及び4.27の 5 種類の異なった模型を用意した. 造波装置の最大発生波高が約 $32 \mathrm{~cm}$ であることを考虑し, 模型 重量を $27 \mathrm{gf}$ 2, $330 \mathrm{gf}$ の範囲で変化させた。全体で模型は 20 種 類用意した。この模型の一覧が表一2に示されている。

この表は, 各行が模型分類番号 $\mathrm{A} \sim \mathrm{E}$ で分類してあるが, これにはHudson式でテトラポッドの安定係数 $\mathrm{K}_{0} \approx 8$ とし, 各

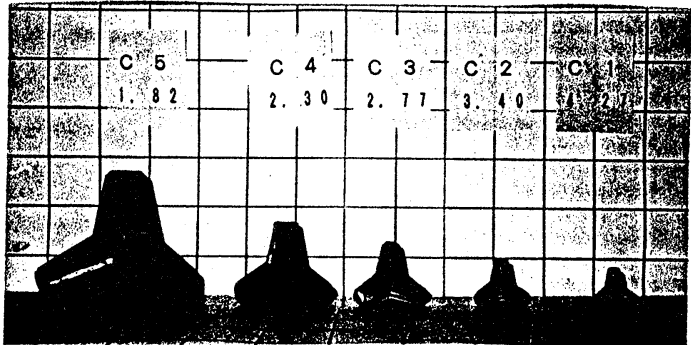

写真一 $1 \mathrm{~K}_{\mathrm{D}}, \mathrm{H}$; 一定, 比重変化による 形状寸法の比較.（表-2の模型分類番号 " C") 分類番号ごとに一定の設計波高（表中には設計波高 $\mathrm{Hc}$ c記し てある）に対して, 各比重（比重番号1 5）のテトラポッド模型が移動を始める所要重量 $\mathrm{W}$ ( $\mathrm{gf}$ )が示してある. しかし,この表中の模型重量は, 型枠の都合上, 計算による所要重量と多少の相違がある. Hudson式を用いて,

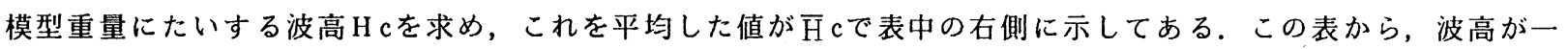
定（模型分類番号が同一）であっても，テトラポッドの安定重量は，比重が重くなるにつれて，軽く済み，形状 高さ（） あ小さくなることがわかる。このことは, 図一1の関係からすわかる，写真一1には，模型分類番号 "C”について形状の比較が示してある。 また, 表一 1 で, B-4, C - 3, D - 2, E - 1 の模型は重量と比 重が異なっているが, 形状寸法（テトラポッドの高さ）は同じになっている。また， B-3，Cー2，Dー1； $\mathrm{C}-4, \mathrm{D}-3, \mathrm{E}-2 ; \mathrm{D}-4, \mathrm{E}-3$ についても, 同様である.

\section{(2) 実験方法}

実験の方法は, 波の周期を一定に保ち, 波高を段階的に大きくする方法で行った。通常, この種の安定性の実 験は, 波高の増大に伴って, テトラポッド模型が移動・脱落するが, 波高のみを段階的に増大させ, 被害率は積 分值として評価する方法が採られる。しかし, 本研究では, 波の作用時間の経過に伴う被害率について詳しく調 べるために, 波高を段階的に増大させるごとに, 移動・脱落したテトラポッド模型を元の位置に再度積み直して から，波を作用させる実験方法を用いることにした。

a)波の打ち上げ（run up）と引き波（back rush）

波の打上げ高と引き波限界については，法面のブロック上にスタッフを置いて，目視と8mmビデオカメラで測定 し静水面から鉊直方向の上下高さに換算した．特に測定を容易にするために，静水面のブロックには赤色で着色 した.

b) 波の作用時間

波の作用時間については，本実験では，造波水槽内に生じる波の再反射をかなり軽減させるよう工夫してある ので, 長時間の波を作用させることが可能である.一般に, 現地海岸で, 高波浪のピーク時の波の継続時間 $\mathrm{t}$ が2 〜3時間であると考えれば, 波の周期 Tを10〜 $15 \mathrm{sec} と し て \mathrm{t} / \mathrm{T}=720 \sim 1,080$ であるから，この程度の数の波を作用さ せることにした。そこで，波の作用によって，ブロックの摇動が見られる場合には， $\mathrm{t} / \mathrm{T}=2,000$ 程度まで波を作用 させることにした，ただし，波の作用によって，ブロックが大きく移動・脱落する場合については，その時点で 波の作用を打ち切った。このように, 従来あまり調べられていない波の作用時間と被害率との関係についても検 討する.

\section{4. 実験結果}

\section{(1) 被害率}

波高の増大に伴なって，テトラポッドは徐々に”摇動”を始め，“移動”し，遂に”脱落”に至る。ブロック の被害については，従来の研究を参考に，次のように分類・定義する.

摇動：ブロックの位置は変化しないが, 微動・摇動する.

移動：摇動と脱落との中間的な場合.

脱落：ブロックの大きさの 1 倍以上移動する.

被害率の定義については，従来より幾つかの方法が考えられてきたが，これらをまとめれば，次のようである. (a) Hudsonは，移動脱落したブロック数の被覆層全ブロック数に対する比率で表わした。ただし波の作用数は数 10 波程度である。 
(b) 任意領域の被覆層全ブロック数に対して, 移動脱落し た個数の比率で表す.

(C)ブロックの移動脱落が下層の捨石達した時, 初期状態 からの移動脱落個数に対する比率で表わす。

以上の(a)，(b，(cの方法は，いずれす波の作用数に対する 考虑がなされていない。@の方法は, 法面勾配が緩やかに なると被覆ブロック総数が非常に多くなるので, 局所的に かなりの被害が発生しても, 被害率は０に近い值となる。 (bの方法は，任意領域の定義があいまいであり，実験者の 主観が入り易い。(@)方法は，被玫ブロックが下層のcore まで移動脱落した個数は，入射波が変わると一定でなくな るので，相対的に画一性が保たれないという欠点がある. このように，いずれの方法す一長一短であるが，本研究で

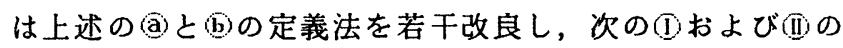
方法を適用することにする。

(1) 波の作用数を, 現地海岸の高波浪ピーク時を想 定して，1,000〜2,000波作用させた後の被害個数 を採用し，被覆層全体のブロック数に対する比率 で表わす.

(i) 図一 2 に示すように, 静水面に平行な層のブロ ック数を100とし，この層における被害ブロック数 を比率で表わす。

（2）(による被害率D

比重が, 被害率 D の時間変化に及ぼす影響を調 べるために，(ず定義した被害率D（以下，特に 指定いない場合，この被害率を示す）を用いて検 討する，比重の影響を調べるために，波の特性（ 波高, 周期, 水深) および模型分類番号が同じ（ $\overline{\mathrm{H}} \mathrm{c}$ が同じ）条件にして，整理した結果が図ー3に 示してある. この図で, 比重の重いRun No.C-1お よびC-2は数波の波の作用で全崩壊したので, 図中 には破線で推定してある。この図中に示す凡例の Run No.のアルファベットは模型の分類番号と対応 している。この図から，比重が重く形状寸法が小 さくなるにつれて，被害が著じるしく大きくなる ことがわかる.この事実はHudson式で $K_{0}$ を一定に し, 比重を变えて単純に計算される結果と大きく 異なる。

\section{(3) (II)による被害率 $\mathrm{D}_{\mathbb{I}}$}

被害率の定義法(1)を適用して, 水平方向に各層 毎に被害率 $\mathrm{D}_{\mathbb{1}}$ を計算し，さらに波の打ち上げ高 $\mathrm{R}_{u}$ と引き波高 $\mathrm{R}_{\mathrm{n}}$ を用いて, 法面上の相対位置 $\mathrm{h}_{\mathrm{E}} /$

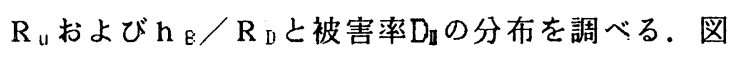
-4 には, 波の特性（水深, 波高, 周期）およ模 型分類番号を固定し，比重変化が被害率 $\mathrm{D}_{\mathbb{1}}$ の分布 に及ぼす影響が示してある。この図から，模型分 類番号と波高が同じであっても，比重の違いによ って，被害分布がかなり異なっている，特に，比 重が重くなるにつれて被害が急激に大きくなる ことがわかる. 比重が変化してもHudsonの関係

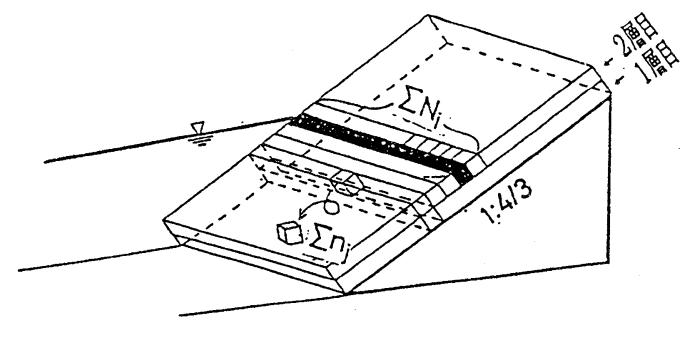

$$
D_{\mathbb{I}}(\%)=\frac{\sum n_{j}}{\sum N_{i}} \times 100
$$

ここに， $\Sigma n_{\mathrm{j}}$ : 上層被覆ブロックで, 対象とする 水平方向の 1 列の中で脱落した個数 $\Sigma N_{i}:$ 上層被覆ブロックの対象とする

図一２被害率 $\mathrm{D}_{\mathrm{a}}$ の定義

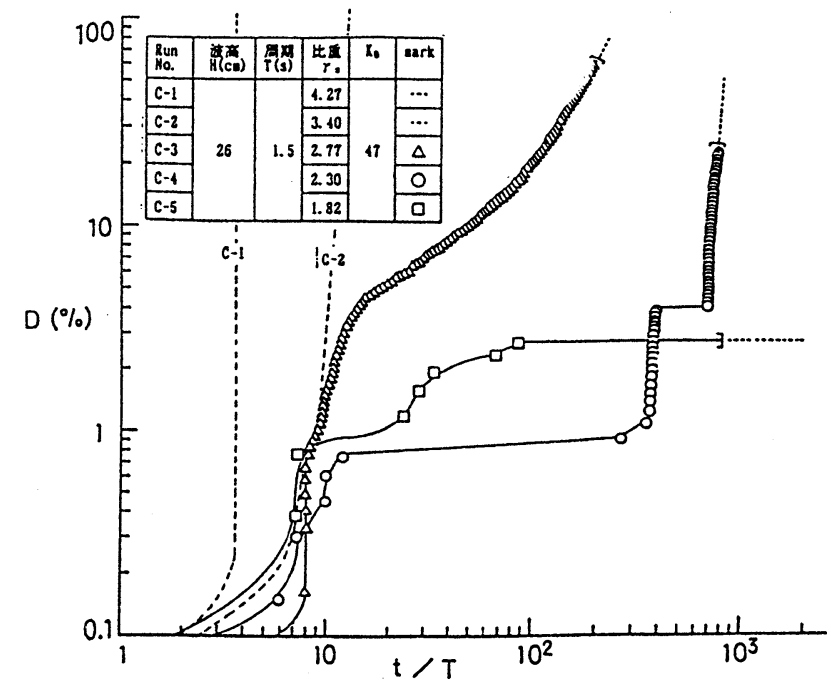

図一 3 波の作用に伴う累加被害率の変化 $\mathrm{H}, \mathrm{T}$, 模型分類番号 : 一定, 比重 : 変化
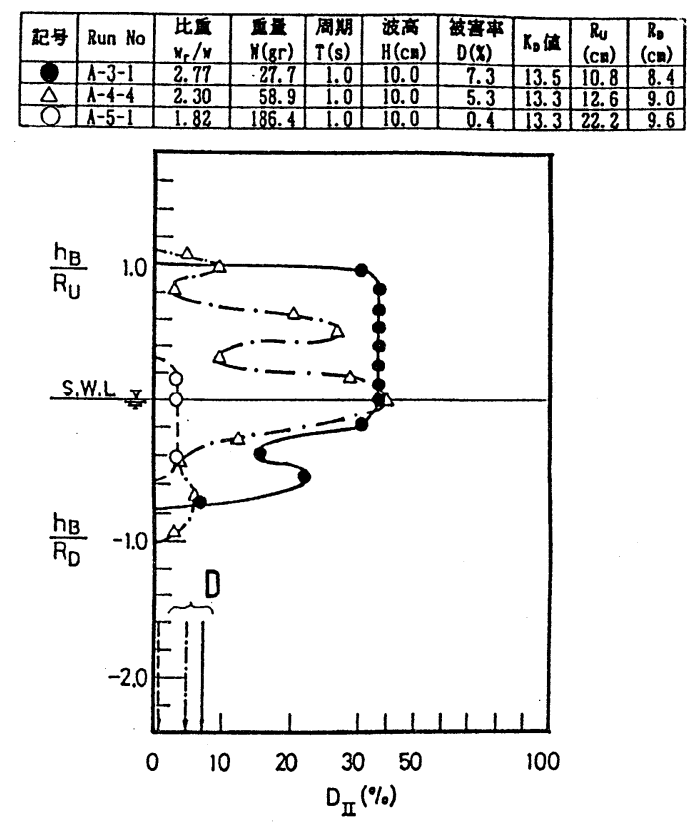

図一 4 被害率 $D_{\mathbb{1}}$ の鉛直分布 $\mathrm{H}, \mathrm{T}$, 模型分類番号 : 一定, 比重 : 変化 
式が普遍的に成立するならば，水理現象は同じになるはずである。しかし， 比重1.82では被害が軽微であるが, 比重4.27では全面崩壊になっている. このことは，われわれの直感的な考えとは一致せず興味深い事実である. なお，参考のために，図の下側には，それぞれのRun No.に該当する線（実 線, 破線など) の矢印で, 最終の波の作用時間における被害率 D の值が示 してある。

\section{7 . 検討}

（1）被害状況と安定係数 $\mathrm{K}_{\mathrm{D}}$

Hud sonは，理論展開において，流体による慣性力，斜面上の砕波流速， 波形勾配等の波の特性, 消波ブロックに関係する形状, 空隙率など諸々の 影響を定数に含めて取り扱い，式を導いている。このように数多くの影響

を含む定数は, 消波ブロックの安 定性を表す指標で, よく知られて いる安定係数 $\mathrm{K}_{\mathrm{I}}$ である。従って， この安定係数は消波ブロックの耐 波性能を表すむのである。

乱積の実験結果に基づいて, 摇 動のみで移動・脱落の無い（被害 率 $\mathrm{D}=0 \%$ ）場合を図一 5 ，aに，ま た移動・脱落による被害が生じた $(\mathrm{D}=0 \sim 1 \%)$ 場合を図－5，bに， それぞれ安定係数 $\mathrm{K}_{\mathrm{D}}$ と比重の関係 が整理してある。これらの図から， K。值はかなりばらついており, 最 低と最高で約 100 倍の幅があり, 比 重の影響をみいだすことはできな い。つこのように， $\mathrm{K}_{\mathrm{U}}$ 值がばらつ く原因として, ブロック重量, 波 高, 比重, 及び斜面勾配を与えて $\mathrm{K}_{\mathrm{D}}$ 值を計算したため，上述のよう な各種の要因の影響が含まれてい るためと考えられる、また，図一 4.bの移動・脱落による被害は, 図一4.aの摇動に比べて, $\mathrm{K}_{\mathrm{V}}$ 值が 多少大きくなっている.

(2) 砕波帯相似パラメーター 波の周期，波高及び法面勾配に よる砕波帯相似パラメーター

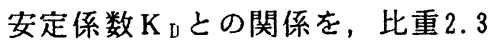
と4.27について整理した結果が図 一6にまとめてある.この図から， $\mathrm{K}_{\mathrm{v}}$ とその関係に比重の影響が入っ ていることがわかる.すなわち， 図一 5 では， $\mathrm{K}_{\mathrm{D}}$ 值が広くばらつい たが、このばらつきの中に砕波帯 相似パラメーターの影響が入って いるためであると考えられる。そ こで, Hudson式による $\mathrm{K}_{\mathrm{D}}$ の表示式 で比重 $w_{r} / w と \xi の$ 効果が現れるよ うに書き直せば,
表一 3 各種模型とその表示記号

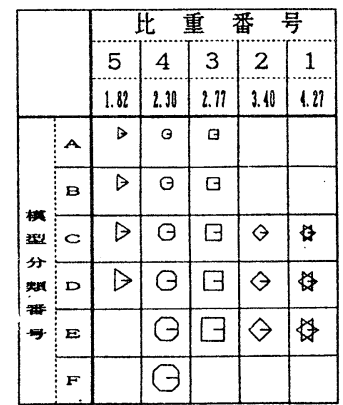

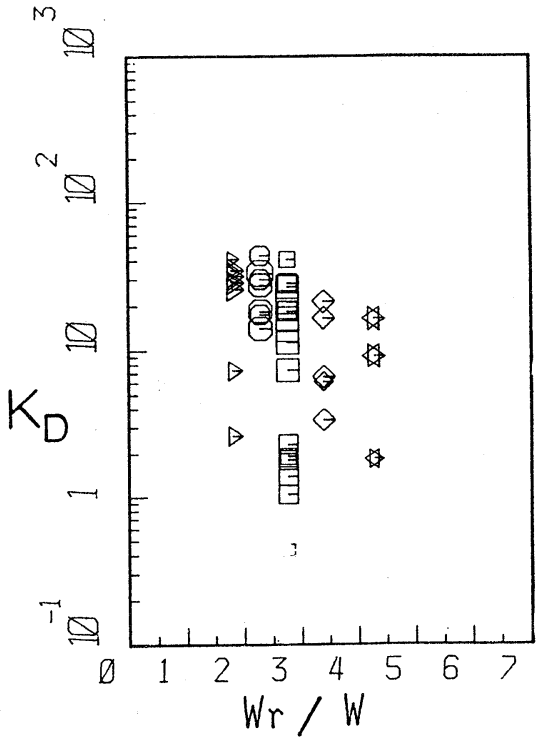

（a）摇動，被害率 D =0\%

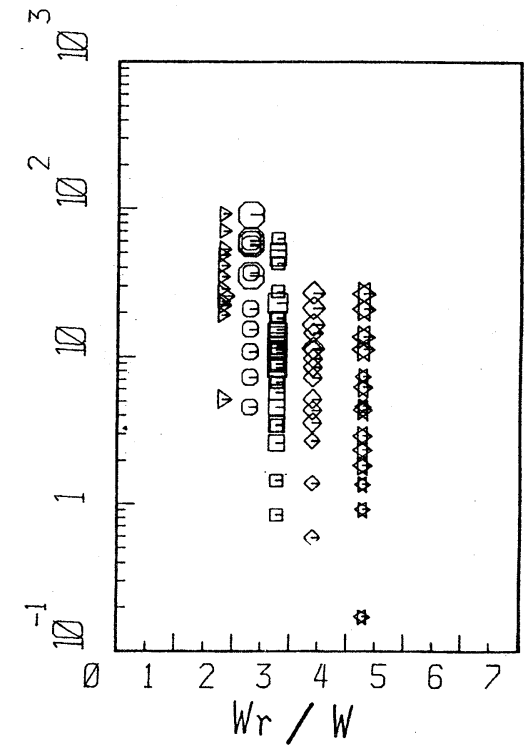

（b）移動・脱落，被害率 D =0 $1 \%$ 図-5 $\mathrm{K}_{\mathrm{V}}$ 值と比重の関係

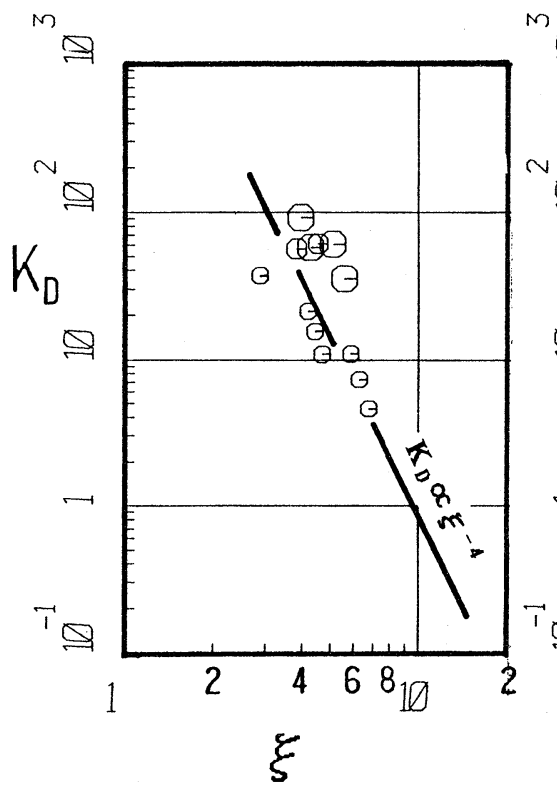

(a)

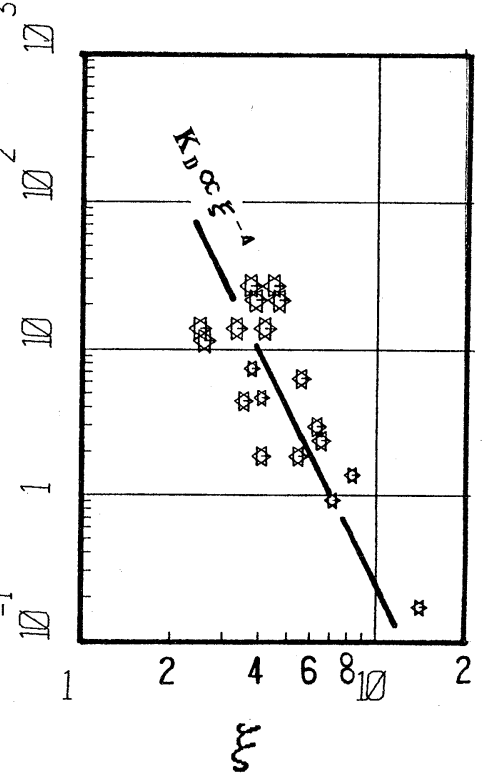

(b) $w_{r} / w=4.27$ 


$$
\mathrm{K}_{\mathrm{I}}=\frac{\mathrm{w}_{\mathrm{r}} \mathrm{H}^{3}}{\mathrm{~W}\left\{\left(\mathrm{w}_{\mathrm{r}} / \mathrm{w}\right)-1\right\}{ }^{3} \cot \alpha}=\frac{\mathrm{N}_{\mathrm{s}}^{3}}{\cot \alpha}
$$

すなわち，

$$
\mathrm{K}_{\mathrm{D}}=\frac{\mathrm{C}}{\xi^{4}\left\{\left(w_{r} / w\right)-1\right\}^{3}}
$$

ここに, C は定数で, 波の特性, 法面勾配, Reynolds数等を含む. $\mathrm{N}_{\mathrm{s}}$ はスタビリティナンバー. 式(5)から得られる $\mathrm{K}_{\mathrm{I}} \propto \xi^{-4}$ の関係が比較の ために図一6に入れてあるが, 実験結果と良く対応していることがわか る.

\section{（3）比重の影響}

図一 5 では，実験結果のばらつきが大きく比重の影響がはっきりしな かったが, 砕波帯相似パラメータ一を用いて整理すると, 図一6のよう にきれいな関係としてまとまることがわかった，そこで，ををパラメー 夕にして， $\xi<4$ 及び $5<\xi \leqq 6$ の範囲に分けて， $K_{0}$ と比重の関係を 整理した結果が図一7に示してある。この図中には, 式(5)から得られ る $\mathrm{K}_{\mathrm{I}} \propto\left(\mathbb{W}_{\mathrm{r}} / \mathrm{w}\right)^{-3}$ の関係が示してある.この関係は実駼結果とよく対応 することがわかる。これまでに，捨石堤のように法面勾配が比較的ゆる やかな場合, $\xi=2 \sim 3 て ゙$ 共振が発生し, 安定性が急隇すると言われてい $ろ^{b)}$. しかし, 本実験では, $\xi$ くの範囲の実験結果が十分無いので, 共 振による安定性を十分検討することができない。

\section{8.まとめ}

（1）規則波を用い，波の再反射が起こらないように工夫した装置を 用いて実験を行い, 被害率の判定むかなり厳密に行った。しかし, 実験 結果を安定係数と比重の関係で整理すると，K。值はかなりばらつき， ばらつきらの幅は約100倍にも達した。

（2） $\mathrm{K}_{\mathrm{D}}$ 値を一定とし，Hudson式を満たすように比重を变えると（表 -2 の模型分類番号を同じになるように，，比重が重くなるにつれて安 定性が低下する。

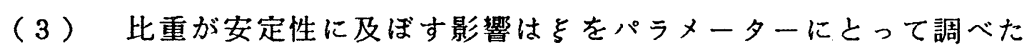
結果, 安定性 ( $\mathrm{K}_{\mathrm{D}}$ 値) は比重のー 3 乗に比例する。

（4）ここでまとめた事柄は, 小中規模の実験に基づいており, 波高及 びテトラポッドの形状寸法によるレイノルズ数 Reミ1 $0^{5}$ であり,この $\mathrm{R}$ e 数の影響を無視して得られた結果であることに留意すべきである.

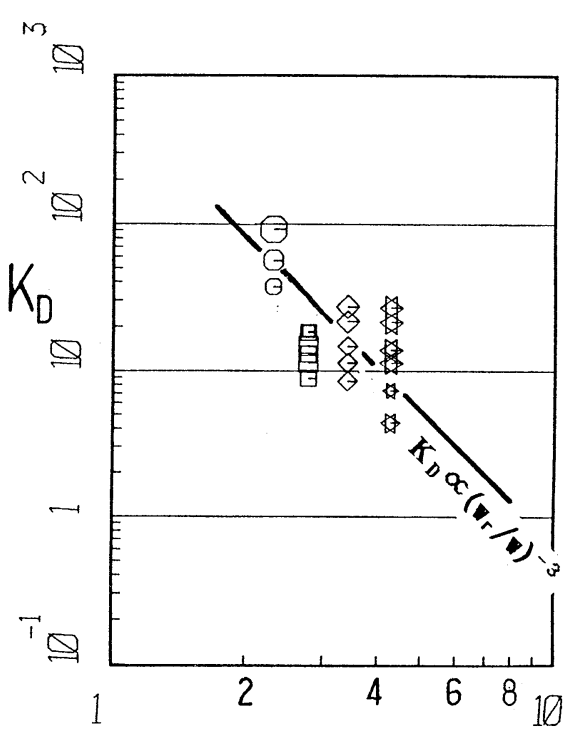

$W_{r} / W$

(a) $\xi<4$

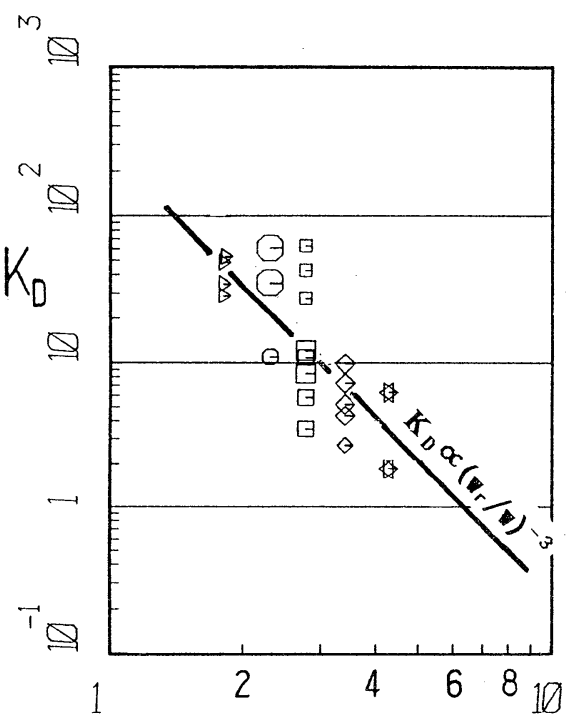

$W r / W$

(b) $5<\xi \leqslant 6$

四一7 そをパラメーターにとった $\mathrm{K}_{\mathrm{D}}$ 值と比重の関係

\section{参考文献}

1 ) Hudson, R. Y. : Laboratory investigation of rubble-mound breakwater, Jour. of Waterways and Harbor Div., WW3, Proc.ASCE, 1959, pp. 93 121.

2) 高吉晋吾・高橋吉弘・徳川和弘：室津港水理模型実験, 調設広報K0BE, Vol. 11, No. 2, pp. 17 27.

3) Zwamborn, J. A. : Dolos packing density and ef fect of relative block density, Proc. 16 th ICCE, 1978, pp. $2285 \sim 2304$.

4) 大中 晋・石畸郁夫・堺 和考：重量ブロックの安定性に関する実験的研究, 土木学会第 45 回年次学術講演 会講演概要集, 1990.9, PP. $820 \sim 821$.

5 ) 伊藤政博・岩垣雄一・山本方人・半沢 稔 ：消波ブロックの比重が安定性に及ぼす影響について, 土木学会 土木学会第 46 年次学術講演会講演概要集, 1991 , PP. $842 \sim 843$.

6) 椹木 亨 - 柳 青魯・大西明徳 : 捨石防波堤斜面上の共振現象による破壊機構, 第 29 回海岸工学講演会 論文集，1982，pp. 428 432 